\title{
草木染めに対するゼオライト処理の効果
}

\author{
鹿児島大学理学部早川 勝光 \\ 鹿児島県大島紬技術指導センター 操利一・赤塚 嘉寛
}

\section{Effect of Zeolite Treatment on Dyeing by Extracts form Plant}

\author{
Katumitu Hayakawa*1, Toshikazu Misao ${ }^{* 2}$, and Yoshihiro Akatsuka*2 \\ -1 Department of Chemistry, Faculty of Science, Kagoshima University, Kagoshima, 890 Japan \\ .2 Kagoshima Prefectural Research Institute of Ohshima Pongee Fabric, Naze, Kagoshima, 894 Japan
}

\begin{abstract}
A traditional dyeing method by plant extracts including treatment with mud adds some excellent properties but poor coloring of textile fabrics. The zeolite was, therefore, tested as a substitute of mud to get natural coloring. The silk yarn dyed in a hot bath of plant extracts was gently crumpled up in zeolite suspension and the effect of the zeolite treatment on weight increment, rubbing fastness, color properties such as $L^{*} a^{*} b^{*}$ and color fastness to light was compared with a traditional dyeing by the plant extracts. The plants used were "Sumomo" fruits (Prunus salicina Lindley) and tree trunks of "Mokkoku" (Temstroemia gymnanthera (Wright et Arn.) Bed. dome), "Yamamomo" (Myrica nubra Sieb. et Zucc.), "Iju" (Schima wallichii (DC.) Korthals). "Itajii" (Castanopsis sieboldii Subsp. Iutchuensis (Koidz.) H.Ohba), and "Sharinbai" (Rhaphiolepis indica (L.) Lindle. ex Ker var. umbellata (Thunb. ex Murry) Ohashi). A silane coupling agent was necessary for the tight adsorption of zeolite to silk fiber and 3 . aminopropyltriethoxysilane was the most effective. The best results of the fastness of dyeing were obtained by the following process of dyeing: dyeing of silk in a hot bath of extracts followed by mordanting with various metal salts and zeolite treatment with a silane coupling agent, and the second dyeing followed by mordanting and finishing with a silicone fiber treatment agent such as softener. About $10 \%$ of weight increment was obtained by the zeolite treatment. which was larger than regular traditional dyeing (2\%) without mud treatment, but less than that with mud treatment ( $35 \%$ by repeated mud treatment in "Doro Ohshima tsumugi"). The rubbing fastness was improved by using the fiber finishing agent containing silicone compounds. A slightly deep color was obtained by the zeolite treatment. The rubbing fastness and the color fastness to light were in a similar grade to a regular traditional dyeing by plant extracts.
\end{abstract}

(Received November 18, 1993).

\section{1. 粕言}

植物からの抽出液を染料溶液とする染色は古くから行 われているが, 各種の優れた合成染料が利用できる現在 でも人々の自然回㷌の龧好を反映して, 各地の伝統産業 として固有の染色法が受け継がれている。その中には, 発色に金属塩を使用しないで，その土地の自然泥を使用 しているものもある〔1]。鹿児島県の特産品である奄美 大島紬はその一つで、シャリンバイ抽出液と Ca 塩で反 復染色してある程度の発色を実現した後, 由泥で処理し て深みのある黑あるいは濃褐色に発色させている。泥染 め絹糸を電子顕微鏡で観察する上，なめらかな絧緎維表
面は，使用されたシャリンバイ抽出液からのタンニン系 化合物と田泥処理による金属イオン複合体や粘土鉱物な どに覆われているのがかかる[2]。この事実が，原料絴

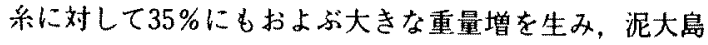
紬独特の深みのある渋い色調や風合い，着心地を作り出 している $[3] 。$

泥染めは，田泥の中に共存する鉄（II）をはじめとす る多種類の金属イオンの媒染効果によってタンニン系化 合物を発色させるものである[1]。しかしながら，金属 イオンごとに光の吸収带が異なっているので，その色合 いは混合色にならざるを得ない。したがって，再現性の あるムラのない染色を実現するためには黒または濃色に 
染めざるを得ないので，天然染料そのままの発色を実現 することは不可能であった。

本研究では，田泥に代わって媒染効果のない白色のゼ オライトを使用して峨維表面を泥染め風にぜオライト粒 子で被得して，高い重量增率による泥染めの風合いと色 彩が豊かな染色が可能かどうかを検討した。その結果，

シランカップリング剂を使用することによって，10\%程 度の重量增率が得られ，媒染剂を選ぶことによって植物 染料の発色をコントロールできることが分かった。

\section{2. 実}

\section{1 试}

染色用絹采には，奄美大島紬用練綃米（108デニール， $100 \mathrm{~T} / \mathrm{m}$ ) を使用した。草木染料の抽出には，奄美大島 原産のすもも (Prunus salicina Lindley)の果実, 奄美大 島の山林より切り出してきたもっこく(Temstroemia gymnanthera (Wright et Arn.) Beddome), ゃまも \& (Myrica mubra Sieb. et Zucc.), いじゅ (Schima ual lichii (DC.) Korthals), いたじい（おきわなじい,Cas tanopsis sieboldii Subsp. lutchuensis (Koidz.) H. Ohba) およびしゃりんばい (Rhaphiolepis indica (L.) Lindl. ex Ker var. umbellata (Thunb. ex Murry) Ohashi) の 樹幹を使用した。媒染郕として酢酸銅（II），酢酸アル ミニウム、硫酸アンモニウムアルミニウム（アンモニウ ムみょうばん），硫酸鉄（II）アンモニウム（モール塩）， 塩化錫（II）を使用した。これらは、すべて特級試薬 (和光純薬)であった。

ゼオライトは，南九州に広く分布するシラスを原料と して水熱合成したシラスぜオライトーP型（サンケイ化 学より供与)を使用した〔4〕。シンカップリング刘に は，3ーアミノプロピルトリエトキシシラン（信越化学 KBE903，信越化学より供与）など数種の試薬（信越化 学 KBE402, KBM403, KBM602, KBM603, KBM803) を比較検討した（図 1)。アニオン性の染料の固着作用 を試験するため，カチオン界面活性郕であるへキサデシ ルトリメチルアンモニウムブロミト（HTAB）を使用し た。仕上げ処理にはシリコーン系瀻維処理訪刂，ソフミン MR-60（三木染料，シリコーン系高分子化合物を主成分 とする乳濁液)，ライトシリコーンM-807 S (共栄社油 脂化学、ポリジメチルシロキサンと多価アルコール高級 脂肪酸エステルを主成分とするペースト）を使用した。

\section{2 染色用抽出做の明慜}

果赛（すもも）の抽出：冷凍保存したすももの果実 1 kg を水 1 Lに浸漬して徐々に昇温した。80９0 ${ }^{\circ} \mathrm{C} て ゙$ 的 1 時間果実が碎けない程度に加熱して着色成分を抽出し た。抽出液を万別して，水で 3 Lに希釈して塩酸一酢酸

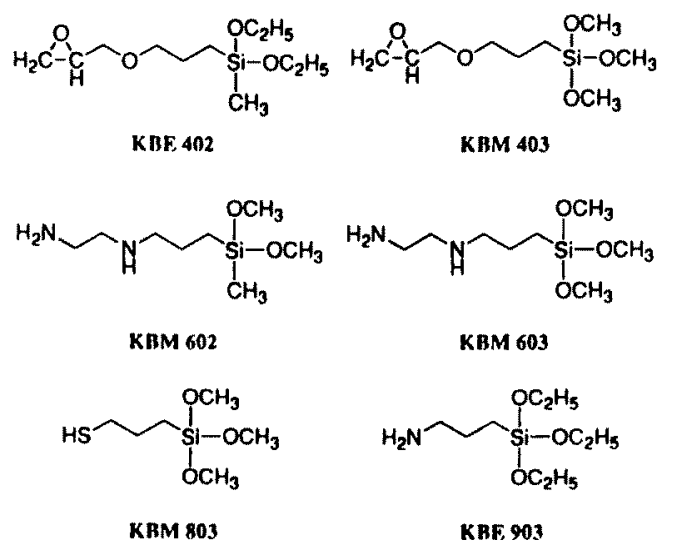

Fig. 1 Molecular structure of silane coupling agents. KBE 402: 3.glycidoxypropylmethyldiethoxysilane, KBM 403: 3-glycidoxypropyltrimethoxysilane, KBM 602: N.2(aminoethyl)-3-aminopropylmethyldimethoxysilane, KBM 603: N-2-(aminoethyl)-3-aminopropyltrimethoxysilane, KBM 803: 3-mercaptopropyltrimethoxysilane, KBE 903: 3-aminopropyltriethoxysilane.

混合系で $\mathrm{pH}$ を2.5３.5に調整して染色液としだ。

樹幹の抽出：もっこく，やまもも，いじゅ，いたじい， しゃりんばいの木片チップ（10 kg）に水を加えて浸漬 し，15 g の炭酸ナトリウムを加えて加熱した。蒸散す る水を補給しながら 8 時間木片チップを加熱し，色素成 分を抽出した。放冷後，抽出液を水で50倍に希秎して染 色液として使用した。

\section{3 染色法}

染色：すもも抽出液による染色の場合には，綟米重量 に対して50倍量（以下，浴比50：1 と略す）の冷染色液 に水洗した綟系を数分間浸漬して絹系を十分に染色液で ぬらした。加熱して $100{ }^{\circ} \mathrm{C} て ゙ 60$ 分間染色した。放冷後, 固くしほって脱水した後，各種金属塩溶液で媒染した。

樹幹抽出液による染色の場合には，絹系を水洗した後， 浴比50：1の染色液に浸漬して加熱し, 約 2 分間黄沸し た後，1時間放冷した。この間，染色ムラが生じないよ うにしばしば綃系を染浴中でかきまぜた。そして脱水し た後、媒染した。

媒染：媒染郕として酷酸銅（II），酢酸了ルミニウム， 硫酸アンモニウムアルミニウム，硫酸鉄（II）アンモ二 ウム，塩化錫（II）を使用した。すもも抽出液による染 色の場合には $10 \%$ owf の媒染剤を，樹幹抽出液による染 色の場合には $5 \%$ owf の媒染剤を溶解した水溶液（浴比 $50 ： 1 ） に$ 染色した組系を30分間浸请し，媒染処理した 後乾㮫した。

界面活性棛処理：媒染した絹系を0.1\%HTABカチ才 
ン界面活性骫水溶液（浴比50：1）に10分間浸漬した後 脱水した。

ゼオライト処理：0.5または $1 \%$ のシランカップリン

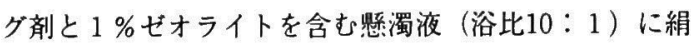
系を浸漬して，2 分間手による加圧とかきまぜを繰り返 した。懸濁液を変えてさらに 2 回処理し，脱水して乾燥 した。

洗埩：ゼオライト処理した絹系を0.1\%非イオン性界 面活性剤（アゾリン）溶液（浴比10：1）に30分間浸漬 した後，十分に水洗した。

仕上げ処理：濃度 $1 \%$ のシリコーン系乳濁液（浴比10 ：1）に，ゼオライト処理染色した絹系を浸漬して 2 分 間処理した後, 脱水, 乾燥した。

\section{4 試}

2.3の各処理による䄉維の重量增加を測定して，絹系 に対する重量增率の値から染着量を評価した。重量変化 は風乾後秤量した。摩擦試験機 I 型（乾燥法）によって, 摩擦に対する染色堅ろう度試験（JIS L0849-1971）を行 って，污染用グレースケールを用いて等級判定した。カ ーボンアーク灯光に対する染色堅ろう度試験（JIS L0842-1988）を行った。第二露光法でサンシャインス ーパーロングライフウェザーメーターWEL-SUM-TC

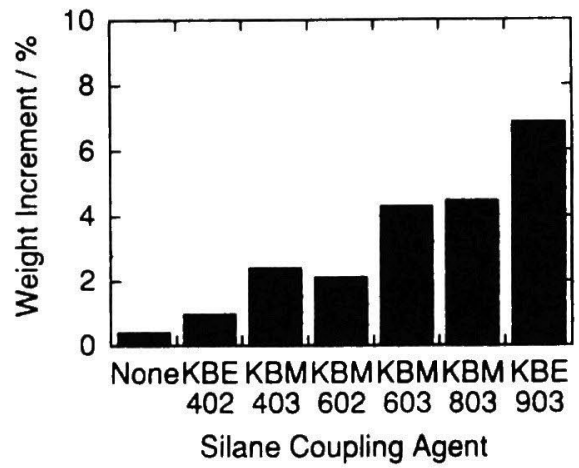

Fig. 2 Dependence of zeolite adsorption on silane coupling agent.

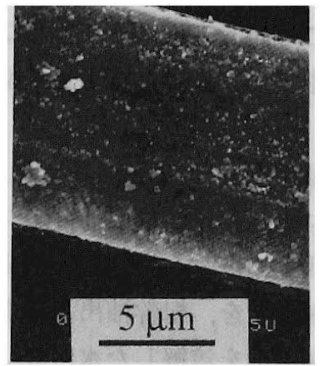

(a)

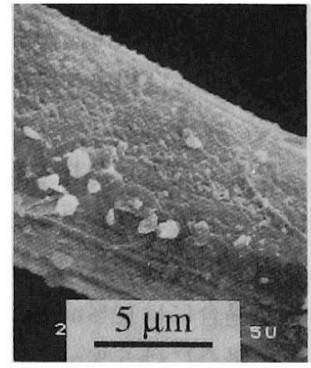

(b)

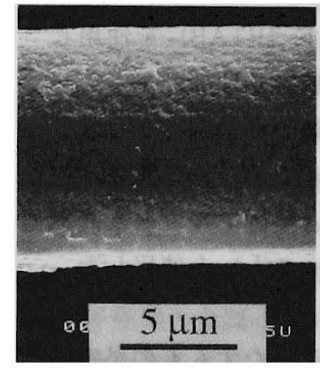

(c)

\section{3. 結果と考察}

\section{1 シランカップリング詴によるゼオライトの吸着}

絹系へのゼオライトの吸着に対する各種のシランカッ プリング剂の効果を比較検討した。シランカップリング 凨は分子内に無機質と反応する官能基（メトキシ基, エ トキシ基など）と有機質と反応する官能基（エポキシ基, アミノ基，メルカプト基など）とを有する有機硅素化合 物であって，有機無機複合体をブレンドするのに使用さ れている[5]。本研究では, 図 1 に示したシランカップ リング剂を用いて，綟䄉維とゼオライトとのカップリン グ剂効果を検討した。濃度1.0\%のシランカップリンク 剤と $1.0 \%$ のぜオライトを含むサスペンションに絹系を 浸漬し，手による加圧とかきまぜを繰り返した後，洗浄， 乾燥してその重量增加を調べた。その結果を図 2 に示し た。シランカップリング剂を使用しない場合、重量增率 は小さい $(0.4 \%)$ が，シランカップリング䍑を使用す ると重量增率は大きくなっている。エポキシ基やジアル コキシシラン基を有するカップリング剤（KBE 402, KBM 403，KBM 602）による重量增率は小さい。トリ アルコキシシラン基を有する場合は $4 \%$ 以上の重量増加 が得られるが, KBE 903が最も効果的である。KBE 903 は，ナイロン樹脂とのカップリング剤として開発された もので[6], 有機質に対する官能基として末端にアミ， 基を有している（図 1)。このためにアミド結合を有す る蛋白質战維である絹釆に対する親和性が大きくなるも のと思われる。アルキル鎖の間にアミノ基が存在すると， 絹系に対する親和性が減少している。粒径10～1 $\mu \mathrm{m}$

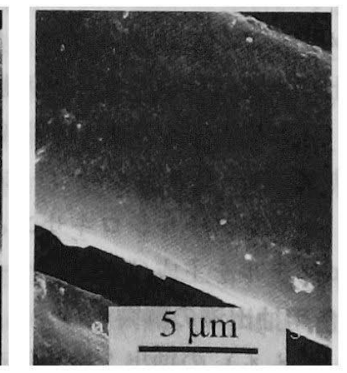

(d)

Fig. 3 SEM photographs of silk surface. Treatment: (a) Z, (b) DMZ, (c) DMZF, (d) DM. The symbols for treatment are described in Table 1. 


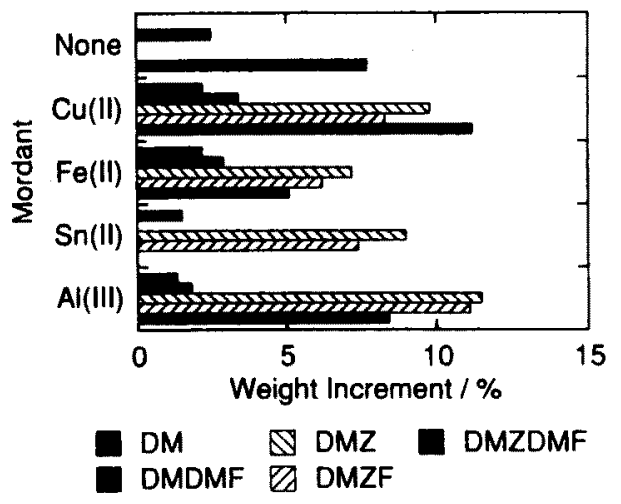

Fig. 4 Dependence of weight increase on the dyeing method. The symbols for dyeing method are described in Table 1.

のゼオライトを使用しているために，走査電子䫓微鏡写 真（図 3 a )を見ると，ゼオライトが絹緉維表面に付着 している様子が分かる。

\section{2 果実（すもも）抽出液による染色}

果実に含まれる色素は安定なものではなく，一般にそ の抽出液で染色した場合耐光堅ろう性に少るといわれて いる。染色操作にゼオライト処理を加えることによる重 量增効果と摩擦および光に対する染色堅ろう性に対する 影響も調べた。

図 4 に染色処理法による重量增加の変化を示した。い ずれの媒染剤を用いても，染色・媒染だけ（DM）では $2 \%$ 前後の重量增加しか得られないが，ゼオライト処理 を加えると，7〜11\%の重量増加が得られた（DMZ）。 図 $3 \mathrm{~b}$ を見ると，この重量増加は，ゼオライト微粒子が 絠䄉維表面に付着するためであることが分かる[2]。こ の微粒子の付着によって，絹独特の光沢が抑制され，泥 処理を施す伝統的な染色法の風合いに類似した効果が現 れる。ソフミンによる仕上げ処理を施すと1－1.5\%の 重量減少が引き起こされる (DMZF)。これは, 䅌䄉維 表面に付着していたぜオライト微粒子が一部はく離する ためと考えられる。

草木染めでは 1 回の染色処理では十分な発色が得られ ないので，一般に染色処理を繰り返す。图 3 は，2回染 色処理を繰り返した場合 (DMDMF，DMZDMF）の重量 增加も示す。ゼオライト処理しない場合，植物の染料成 分と媒染剂との複合体が䄉維に吸着するため，染色処理 を繰り返すことによって重量が増加している（DM， DMDMF を比較)。ゼオライト処理したものでは，染色 操作を絽り返すことによって吸着ゼオライトがはく離す るため，重量增加率が小さくなるが，酢酸銅を媒染郕と した場合は，11\%もの重量増加率を示した。Cu（II）
Table 1 Rubbing Fastness and Color Fastness to Light of Dyeing by Extracts from "Sumomo" Fruits

\begin{tabular}{|c|c|c|c|}
\hline Mordant & Method* & $\begin{array}{c}\text { Rubbing } \\
\text { Fastness } \\
\text { (Grade) }\end{array}$ & $\begin{array}{c}\text { Color Fastness } \\
\text { to Light } \\
\text { (Grade) }\end{array}$ \\
\hline \multirow{2}{*}{ None } & DMF & $4-5$ & - \\
\hline & DZDF & $4-5$ & - \\
\hline \multirow{6}{*}{ Copper (II) acetate } & DMF & $4-5$ & 3 \\
\hline & DMDMF & $4-5$ & - \\
\hline & DMZ & 4 & - \\
\hline & DMSZ & 4 & 3 \\
\hline & DMZF & $4-5$ & 3 \\
\hline & DMZDMF & $3-4$ & - \\
\hline \multirow{6}{*}{$\begin{array}{l}\text { Iron (Il) } \\
\text { ammonium sulfate }\end{array}$} & DMF & $4-5$ & 3 \\
\hline & DMDMF & $4-5$ & - \\
\hline & DMZ & 4 & - \\
\hline & DMSZ & $4-5$ & 3 \\
\hline & DMZF & $4-5$ & 3 \\
\hline & DMZDMF & $4-5$ & - \\
\hline \multirow{6}{*}{$\begin{array}{l}\text { Aluminium } \\
\text { ammonium sulfate }\end{array}$} & DMF & $4-5$ & 2 \\
\hline & DMDMF & 4 & - \\
\hline & DMZ & 4 & - \\
\hline & DMSZ & 4 & $1-2$ \\
\hline & DMZF & $4-5$ & $1-2$ \\
\hline & DMZDMF & 4 & - \\
\hline \multirow{4}{*}{ Tin (II) chloride } & DMF & $4-5$ & 2 \\
\hline & $\mathrm{DMZ}$ & $4-5$ & - \\
\hline & DMSZ & 4 & 2 \\
\hline & DMZF & $4-5$ & $1-2$ \\
\hline
\end{tabular}

* DMF: dyeing (D), mordanting (M) and finishing (F), DMDMF: repeated dyeing and mordanting, and finishing $(F)$ by "Sofmin", DMZ: dyeing, mordanting and zeolite treatment ( $Z$ ), DMSZ: dyeing, mordanting, surfactant treatment $(S)$ in HTAB solution. and finishing. DMZF: DMZ and finishing. DMZDMF: repeated dyeing and mordanting, zeolite treatment and finishing.

イオンでは，䊗維表面での複合体形成による重量増加が， ゼオライトのはく離による重量滅少よりも大きくなるこ とを示している。

摩擦および光に対する染色堅ろう性を表 1 に示した。 ゼオライト処理を施さない場合（DM，DMF）は，45 級の摩擦に对する染色堅万う性が得られているが，ゼ オライト処理を加えると 4 級べと堅ろう性が低下してい る (DMZ)。これは，ビオライトの絧擮維への吸着状態 が不十分で、はく蜼することによると考えられる。一般 
に，シランカップリング剂の作用機構は、有機、無機それ ぞれの材料に对する化学結合によるものとされている 〔6〕。無機系材料に対する作用機構は，アルコキシ基の 加水分解によって生成するシラノール基と材料表面の水 酸基との間の脱水縮合反応に上る共有結合によると考え られていて[7]，材料によっては，赤外スペクトルや NMR スペクトルによる証拠も得られている[8-10]。有 機材料に対する作用機構は，化学結合によるという直接 の証拠はなく，有機ポリマーとのぬれや相溶性の改善に よるとの説もあり、これは個々の材料の性質に依存する [11]。希薄水溶液中でアミノ基と絧轹維の官能基との化 学反応は考え難く、はく蜼しゃすいことなどから、シラ ンカップリング滖の作用は相溶性の改善など分子間力に よるものと考えるのが妥当である。いずれの結合モデル によるにしても，ゼオライトの粗い粒子と滑らかな粗紻 維表面との接触は，図 3 aに示すとおり，不十分である ために結合力は弱くはく蜼しやすいものと考えられる。

ゼオライト処理した染色絹系の表面は图 3 b に示すよ うな状態であるので，製織時に系のすべりに問題が生じ た。そこで，シリコーン系緉維処理戍であるンフミンに よる仕上げ処理を行うと，その平滑作用によって，製織 時の糸のすべりが大きく改善されることが分かった。ま たソフミンで仕上げ処理することによって摩擦に対す る堅ろう性の低下を改善できた（表 1，DMZ と DMZF を比較)。これは，ソフミンによる仕上げ処理によって， 图 $3 \mathrm{c}$ に示すように，ゼオライト粒子と絹檥維とのぬれ を改善し，滑らかな絹转維表面を形成するためである。

耐光試験結果は，ビオライト処理の有無に関わらず 2 一 3 級である（表 1 )。すもも果実による草木染めが耐 光性に劣ることは広く知られていたことであるが，ゼ才 ライト処理による改善は見られなかった。

摩擦に对する染色堅ろう度がゼオライト処理により低 下した。それは，pH 3 程度の酸性浴で染色した絹系を， ゼオライト処理の過程でアルカリ性の処理浴で処理する ことによって，染料の酸解離が進行して水溶性となるた めと考えられる。このような湿潤堅ろう性を改善するた めに染料固着凨としてカチオン性の樹脂や縮合化合物, 界面活性版などが使用されている。これは，ア二オン性 の染料成分とカチオン性化合物との不溶性コンプレック スを形成させることによって湿閏堅ろう性を改善するも のである。アルカリ性のゼオライト処理浴で処理する前 に，この固着郕処理によって染料を固着させることによ って摩擦に対する染色堅ろう性の改善を検討した。高分 子系の固着郕の場合，染色絹系の柔らかみを損なうこと が多いので，カチオン界面活性剂であるへキサデシルト リメチルアンモニウムブロミド（HTAB）で処理してそ

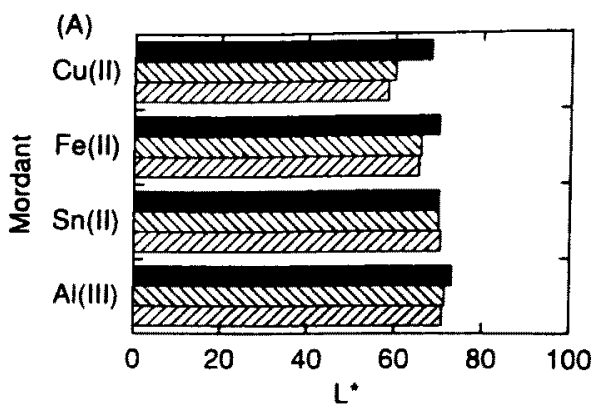

$\mathrm{DM}(\mathrm{a}) \quad \mathrm{DMZ}(\mathrm{b}) \quad \square \mathrm{DMZF}(\mathrm{c})$

(B)

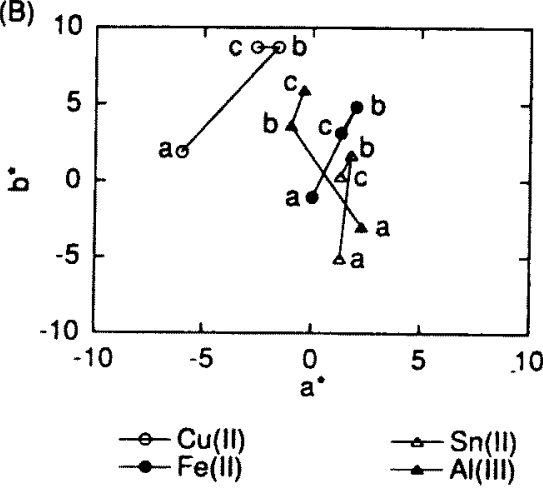

Fig. 5 Dependence of luminosity $L^{*}(A)$ and chromatic index $\mathrm{a}^{*}$ and $\mathrm{b}^{*}(\mathrm{~B})$ on mordant and the dyeing method. $\mathrm{Cu}$ (II): copper( II) acetate, $\mathrm{Fe}$ (II): iron( II) ammonium sul. fate, $\mathrm{Sn}$ (II): $\operatorname{tin}$ (II) chloride, Al(III): aluminium ammonium sulfate. The symbols for dyeing method are described in Table 1.

の効果を比較した（表1の DMSZ）。いずれの媒染俨を 用いても，HTABによる界面活性剂処理によって摩擦や 光に対する染色堅ろう性が改善されることはなかった。

ゼオライト処理による色彩の变化を， L*a* $\mathrm{b}^{*}$ 表 色系の数值変化によって検討した。図 5 Aに示すとおり， ゼオライト処理すると L*が小さくなっていて，浱色に 染まるのを反映している。そのために $\mathrm{a} *$ * $\mathrm{b}^{*}$ により 色度の変化を知ることができるが，ゼオライト処理によ り、すべての場合に $\mathrm{b}$ *が正の方向にシフトしていて黄 色系が強くなっている（図 $5 \mathrm{~B}$ の $\mathrm{a} \rightarrow \mathrm{b}$ または $\mathrm{a} \rightarrow \mathrm{c}$ )。 これらの色度の変化は，吸着したゼオライト徽粒子によ る光の散乱の影橥とアミノ基を有するシランカップリン ク凨の金属イオンとの錯体の形成が関係しているものと 考えられるが，それぞれの反射スペクトルへの影䈉を明 らかにするには，さらに基硙研究を行う必要がある。

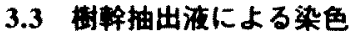

樹幹抽出液による草木染めは，一般に日光に対する染 
色堅ろう性に優れると評価されている。そこで，樹幹抽 出液による草木染めに対するゼオライト処理の効果を調 べだ。使用した樹種は，もっこくややまもも、いじゅ， いたじい、しゃりんばいである。この場合，せオライト 処理する前に, HTABによる界面活性郕処理を全ての場 合に行った。また，仕上げ処理には，シリコーン系処理 剤であるライトシリコーンM-90Fを使用した。

アルミニウム媒染と銅（II）媒染した場合の重量增加 を図6に示す。ゼオライト処理を行わない場合，染着度 が小さく淡い色にしか染まらなかったので，染色と媒染 の操作を 2 回絽り返した（DMDM）。また，染色と媒染 操作をゼオライト処理の前後に繰り返した場合の結果も 示す (DMSZDMF)。

アルミニウム (III) 媒染（図 $6 \mathrm{~A}$ ) では, ゼオライト 妈理しない場合（DMDM）の重量変化は $3 \sim 5 \%$ であ るが，ゼオライト处理することによって 9 - $12 \%$ の重量 增加率を得た（DMSZF，DMSZDMF)。銅 (II) 媒染の 場合（図6 B ）をみると，しゃクんばいではゼオライト 処理を加えなくても，9.4\%にも及占重量增率が得られ ている。銅（II）媒染では，ゼオライト処理を加えない 場合の重量增率はアルミニウム媒染よりも大きい。この ことは抽出液中には銅（II）イオンと不溶性のコンプレ ックスを形成しやすい成分が存在することを示している。 ゼオライト処理を加えると（DMSZF，DMSZDMF），重 量增率は10－14\%と大きくなる。アルミニウム媒染では， ゼオライト処理後の 2 度目の染色・媒染処理によってわ ずかの重量隇少が見られるが，銅（II）媒染では增加す るものが多い（図 6)。これは銅（II）イオンとの不溶 性コンプレックスの形成が，ビオライトのはく離よりも 大きいためと考えられる。いずれの場合もゼオライト処 理により大きな重量增率が得られ，伝統的な泥大島紬の 風合いの奏現に好ましい効果を与えることを示している。

表 2 に摩擦と光に対する染色堅ろう性を示した。アル ミニウム媒染の場合，摩擦に对寸る染色堅万う性の低下 は見られない(第 3 欄。DMDMとDMSZを比較)。銅 （II）媒染の場合には，ゼオライト処理することによっ てかなり改善される(第 5 欄。DMDM とDMSZを比較)。 しかし，さらに染色と媒染を繰り返すと，摩擦に対する 堅ろう度の低下が起こる（DMS2DM）。これは，植物抽 出液による染色と媒染を繰り返す草木染めは，絹織維の 非結晶部分への染料成分の浸透固着に基づくものではな く, 峨維表面への染料成分と金属イオンとの不溶性コン ブレックスの沈着によるためと考えられる（図 $3 \mathrm{~d} ） 。$ したがって，合成染料による染色に較べて重量増率が大 きくなる。

ポリジメチルシロキサンと多価アルコール高級脂肪酸

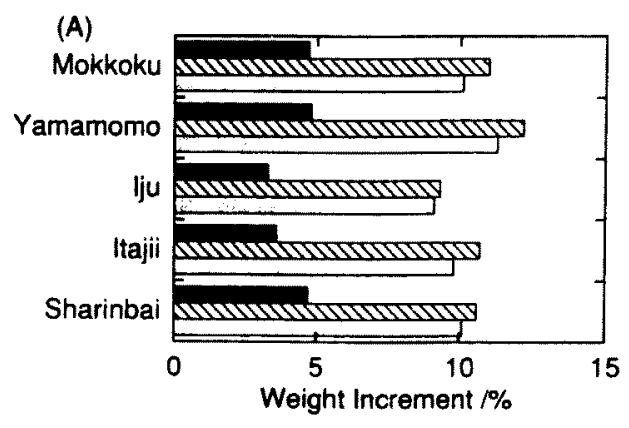

DMDM D DMSZ $\square$ DMSZDM

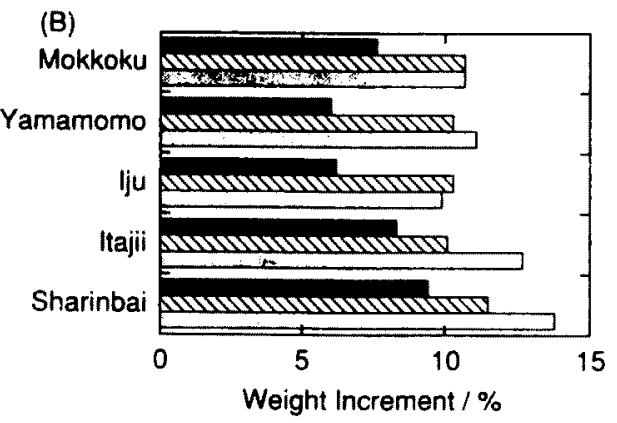

Fig. 6 Dependence of weight increase on tree extracts and the dyeing method. A: mordanting by aluminium ammonium sulfate and $B$ : mordanting by copper( II) acetate. The symbols for dyeing method are described in Table 1 . The tree names are described in Table 2 .

エステルを主成分とするライトシリコーン M-90 Fによ る仕上げ処理を行うと，アルミニウム媒染では，摩擦に 对する染色堅万う性は，明らかに改善されている(表 2 の第 4 欄を第 3 祭と比較)。銅（II）媒染の場合にも， やまももを例外とするが，その他ではライトシリコーン 処理によって摩擦に対する染色堅ろう性が改善される (第 6 欄を第 5 欄と比較)。これも染料を吸着したゼオ ライトのはく觹が抑制されることによる(図 $3 \mathrm{c}$ 参照)。

耐光性については，ゼオライト処理により1䄲程度低 下している。アルミニウム媒染ではその等級は 1 から 3 級でいずれの染色法でも耐光性は小さい。ライトシリコ ーンによる仕上げ処理によって酎光性が改善されること はない。

ゼオライト処理による明度指数 L の変化を図 7 に示 した。DMDMはゼオライト処理しない場合, DMSZFと DMSZDMFはゼオライト処理を行った場合である。 DMDM とDMSZDMFでは 2 回染色・媒染を行っている。 L*は染色回数に依存すると考えられる。すなわち，1 回の染色では $\mathrm{L}^{*}$ が大きく(DMSZ)，2 回染色すると濃 
Table 2 Fastness for Traditional Dyeing by Extracts from Tree Trunks(Mordant: Aluminium Acetate)

\begin{tabular}{|c|c|c|c|c|c|c|c|c|c|}
\hline \multirow{3}{*}{ Tree $^{31}$} & \multirow{3}{*}{ Method ${ }^{b \prime}$} & \multicolumn{4}{|c|}{$\begin{array}{l}\text { Rubbing Fastness } \\
\text { (grade) }\end{array}$} & \multicolumn{4}{|c|}{$\begin{array}{c}\text { Color Fastness to Light } \\
\text { (gr ade) }\end{array}$} \\
\hline & & \multicolumn{2}{|c|}{ Aluminium Acetate } & \multicolumn{2}{|c|}{ Copper (II) acetate } & \multicolumn{2}{|c|}{ Aluminium Acetate } & \multicolumn{2}{|c|}{ Copper (II) acetate } \\
\hline & & $\begin{array}{c}\text { Before } \\
\text { Finishing }\end{array}$ & $\begin{array}{c}\text { After } \\
\text { Finishing }\end{array}$ & $\begin{array}{c}\text { Before } \\
\text { Finishing }\end{array}$ & $\begin{array}{c}\text { After } \\
\text { Finishing }\end{array}$ & $\begin{array}{c}\text { Before } \\
\text { Finishing }\end{array}$ & $\begin{array}{c}\text { After } \\
\text { Finishing }\end{array}$ & $\begin{array}{c}\text { Before } \\
\text { Finishing }\end{array}$ & $\begin{array}{c}\text { After } \\
\text { Finishing }\end{array}$ \\
\hline \multirow{3}{*}{ "Mokkoku" } & DMDM & 3 & - & 2 & - & 3 & - & 4 & - \\
\hline & $\operatorname{DMSZ}(\mathrm{F})$ & 3 & 4 & 4 & 4 & 2 & 2 & 3 & 3 \\
\hline & $\operatorname{DMSZDM}(\mathrm{F})$ & $3-4$ & 4 & $2-3$ & $3-4$ & 2 & 3 & $3-4$ & $3-4$ \\
\hline \multirow{3}{*}{ "Yamamomo" } & DMDM & 3 & - & 2 & - & $2-3$ & - & 4 & - \\
\hline & $\operatorname{DMSZ}(F)$ & 3 & $4-5$ & 4 & $3-4$ & 3 & $3-4$ & $3-4$ & 4 \\
\hline & $\operatorname{DMSZDM}(\mathrm{F})$ & 4 & $4-5$ & 3 & $4-5$ & $3-4$ & $3-4$ & 4 & 4 \\
\hline \multirow{3}{*}{ "lju" } & DMDM & 3 & - & 2 & - & $2-3$ & - & 4 & - \\
\hline & $\operatorname{DMSZ}(F)$ & 4 & $4-5$ & 3 & 3 & $1-2$ & 2 & $3-4$ & 4 \\
\hline & $\operatorname{DMSZDM}(\mathrm{F})$ & 3 & 4 & 2 & 2 & $1-2$ & $1-2$ & $3-4$ & $3-4$ \\
\hline \multirow{3}{*}{ "Itajii" } & DMDM & 3 & - & 2 & - & 3 & - & $4-5$ & - \\
\hline & $\operatorname{DMSZ}(F)$ & 4 & $4-5$ & 4 & $4-5$ & 2 & $2-3$ & $3-4$ & $4-5$ \\
\hline & DMSZDM $(F)$ & 3 & $4-5$ & $2-3$ & 4 & 3 & 3 & 4 & $3-4$ \\
\hline \multirow{3}{*}{ "Sarinbai" } & DMDM & 3 & - & 2 & - & $2-3$ & - & 4 & - \\
\hline & $\operatorname{DMSZ}(\mathrm{F})$ & 3 & 4 & 3 & $3-4$ & $1-2$ & $1-2$ & $3-4$ & $3-4$ \\
\hline & DMSZDM (F) & 3 & $3-4$ & 2 & $4-5$ & 2 & $1-2$ & $3-4$ & $3-4$ \\
\hline
\end{tabular}

a"Mokkoku": Temstroemia gymnanthera (Wright et Arn.) Beddome, "Yamamomo": Myrica mbra Sieb. et Zucc, "lju": Schima wallichii (DC.) Korthals, "Itajii": Castanopis sieboldii Subsp. Iulchuensis (Koidz.) H. Ohba, and "Sharinbai": Rhaphiolepis indica (L.) Lindl. ex Ker var. umbellata (Thunb ex Murry) Ohashi

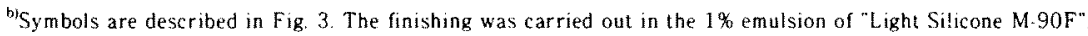
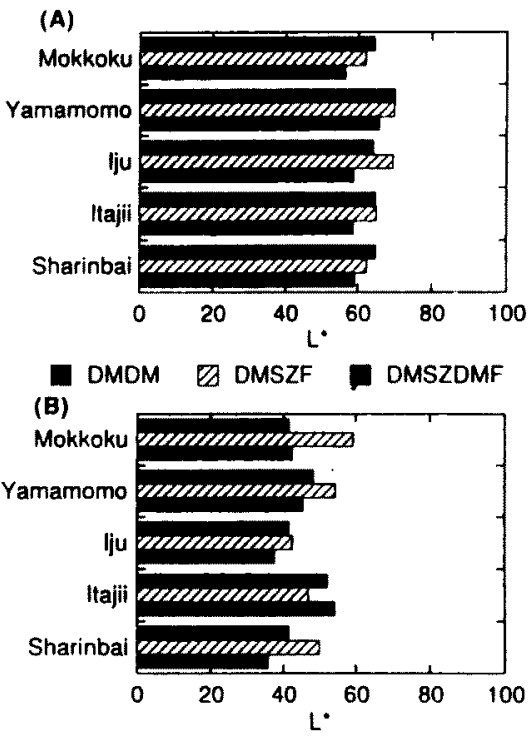

Fig. 7 Dependence of luminosity $L^{*}$ on tree extracts and dyeing method. A: mordanting by aluminium ammo nium sulfate and $B$ : mordanting by copper (II) acetate. The symbols for dyeing method are described in Table 1.
色に染まるため明度が小さくなっている (DMSZDMF)。 2 回染色した場合で較べると (DMDM と DMSZDMF), アルミニウム媒染では，ぜライト好理によりL*は小 さくなっている。銅（II）媒染では，し*はほとんど変 化しない（もっこく、いたじい）か，小さな城少が見ら れる。これはもともとL*の小さな銅（II）媒染では， ゼオライト処理の效果が小さくなるためである。

図 8 には色度の変化を示した。aはゼオライト処理し ない場合、 bとcはぜオライト処理を行った場合である。 a と c では2 回染色・媒染を行っている。 $a^{*}, b^{*}$ は, aからbへとかなり変化するが，ゼオライト処理後にも う 1 回染色・媒染を行うと（c)，aに近づく。いたじ いによる銅（II）媒染では，b*の大きな低下が見られ るが，他の場合，a と c の比較では著しい色度の変化は なく，目視できるような色彩の変化を観察することはな がった。

最後に，各処理每の重量增加率の变化を图9に示した。 いずれの場合もゼオライト処理によって大きな重量增が 起こり，その後の処理によってぜオライトのはく㒕によ り重量堿が生じることを示している。この事実は、シラ 
(A)

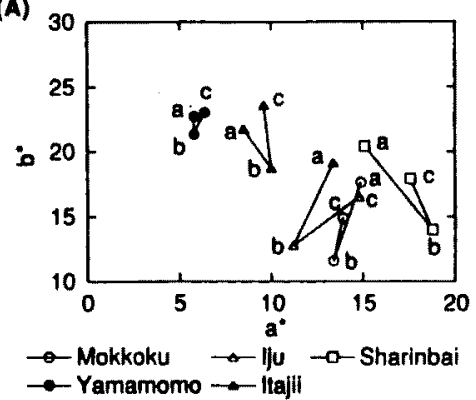

(B)

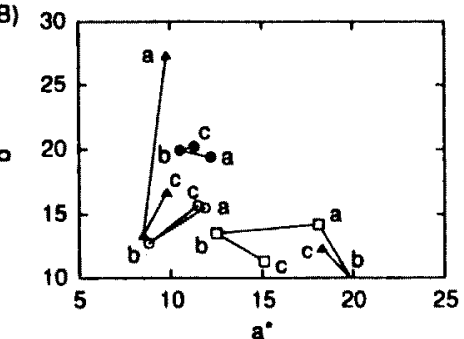

Fig. 8 Dependence of chromatic index $a^{*}$ and $b^{*}$ on tree extracts and dyeing method. A: mordanting by aluminium ammonium sulfate and $B$ : mordanting by copper (II) acetate, a: DMDM, b: DMSZF, c: DMSZDMF.

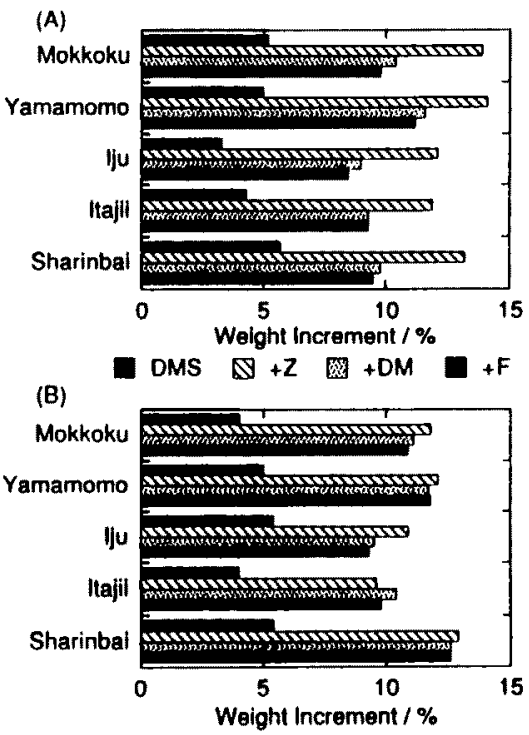

Fig. 9 Dependence of weight increase after each step on tree extracts. A: mordanting by aluminium ammonium sulfate and $B$ : mordanting by copper (II) acetate. DMS after DMS, + Z; after DMSZ, + DM: after DMSZDM, and $+F$ : after DMSDMF where the symbols are described in Table 1.

ンカップリング剤の作用機楧は，有機，無機それぞれの 材料に対する化学結合によるものとされているが, 前述 のように，ゼオライトの粗い粒子と滑らかな組織維表面
との接触が不十分であるために，結合力は弱く，はく離 しやすいことを示す（図 3 a)。すなわち，シランカッ プリング剂を使用することによってゼオライトは絹系に 吸着するが，その吸着力は大きなむのでなく，比較的は く離しやすいということを示している。

\section{4. 結窟}

草木染めに対するゼオライト処理の影晦を調べた結果， 次のことが明らかになった。ゼオライト処理によって $10 \%$ 程度の重量増加が得られ，草木染めのみに較べて泥 大島紬の風合いを演出するのに好ましい結果を与えた。 まだ，ビオライト処理を併用すると，1回当たりの染色 処理による染料成分の吸着が大きくなって濃色に染まる ことが分かった。しかしながら，アルミニウム媒染では， 摩丵や日光に対する染色堅ろう性を改善することはでき なかった。銅（II）媒染では多くの樹種による草木染め に対して摩擦に对する堅万う性がかなり改善されること が分かった（2級から4級に改善）。果実（すもも）に よる草木染めに对するゼオライト処理の効果は, 重量増 に效果がみられたが，摩擦や日光に対する堅るう性は標 準法とほとんど变らなかった。

付記：本研究の一部は，第34回染色化学討論会，1992 年7月（大阪）で発表した。

\section{文献}

1. 皆川 基,「租の科学」, 関西衣生活研究会, p.158 (1981).

2、早川勝光, 赤塚嘉筧, 鹿児島大学理学部紀要（数学 - 物理学・化学編)，24，93 (1991)。

3. 石畨 博, 大人形安樹子, 村田博司, 白久秀信, 西 元研了，赤塚嘉䆓，鹿児島県立短期大学紀要，自然 科学篇，41，71 (1990).

4.サンケイ化学技術資料「シラスゼオライト」.

5。伊藤邦夫編，「シリコーンハンドプック」，日刊工業 新閶社, p.55 (1990).

6. 信越化学工業カタログ、「シランカップリング剂」

7. H. Ishida and J. L. Koenig. J. Collord Interface Sci, 64, $565(1978)$

8. L. M. Johnson and T. J. Pinnavaia, Langmuir, 7 . 2636 (1991).

9. N. Nishiyama, K. Horie, and T. Asakura, J. Colloid In. terface Sci., 129, 113 (1989)

10. N. Nishiyama, N. R. Shick, and H. Ishida, J. Colloid Interface Sci., 143, 146 (1991).

11. 吉岡 博「シリコーンハンドブック」(伊藤邦雄編), 日刊工業新聞社, p.63(1990) 